\title{
ReVeiwArticle
}

\section{A review on biogeochemical linkages of climate change and change in intensity of ultra violet radiation}

\author{
SOUMYA KUMAR SAHOO, JYOSTNARANI PRADHAN, V.B. KURUWANSHI AND ARTI GUHEY
}

\begin{abstract}
SUMMARY
Changes in climate and intensity of ultraviolet radiation can both have substantial impacts on the biological, geological, chemical, and physical processes that control the exchange of matter and energy between the major components of the environment - the atmosphere, the biosphere, the hydrosphere, and the lithosphere. The carbon cycle is of central importance in the climate change issue because human disruption of the natural carbon cycle, through the burning of fossil fuels and the clearing of forests, is largely responsible for the modern increase in atmospheric concentrations of carbon dioxide, the most abundant anthropogenic greenhouse gas. One of the more important links in the carbon cycle from an atmospheric perspective is the so-called "marine biological pump". This is a process in which plankton, the microscopic plants and animals that live near the surface of the oceans and freshwater lakes remove carbon from the air and then transfer it to the ocean bottoms and lakebeds when they die. Ozone depletion, particularly severe episodes such as the spring ozone holes in the Antarctic, present a potentially serious threat to this process, because plankton cannot take shelter from solar radiation. A serious decline in their numbers as a result of exposure to more intense ultraviolet radiation could therefore decrease the rate at which carbon dioxide is removed from the atmosphere. Similarly, biological changes initiated by changes in climate might have some effect on ozone depletion. Methyl chloride and methyl bromide are two ozone-depleting compounds. However, because natural sources of these gases are larger than the human industrial sources, anything affecting the ecosystems and natural processes that produce these gases could also have consequences for the ozone layer. Coastal marshes appear to be important contributors of natural source. Fungi, crops such as rapeseed, and soils rich in organic matter are also thought to be substantial sources. Warming of the atmosphere and oceans or changes in sea level could affect all of these sources by altering the ecosystems and climatic conditions that support the natural production of these gases. Climate change could also affect the rate at which these gases are removed from the atmosphere by the oceans. Studies of the natural production and removal of these gases are still in their early stages, however, and it is not yet possible to predict how climate change might affect the quantities of these gases in the atmosphere.
\end{abstract}

\section{MEMBERS OF THE RESEARCH FORUM}

Author to be contacted :

SOUMYA KUMAR SAHOO, Department of Plant Physiology, College of Agriculture, Indira Gandhi Krishi Vishwavidyalaya, RAIPUR (C.G.) INDIA Email : sahoosoumya5@gmail.com

Address of the Co-authors:

JYOSTNARANI PRADHAN, Department of Plant Physiology, Institute of Agricultural Sciences, Banaras Hindu University, BANARAS (U.P.) INDIA

V.B. KURUWANSHI AND ARTI GUHEY, Department of Plant Physiology, College of Agriculture, Indira Gandhi Krishi Vishwavidyalaya, RAIPUR (C.G.) INDIA
Key Words : Green house effect, Marine biological pump, Ozone depletion

How to cite this article : Sahoo, Soumya Kumar, Pradhan, Jyostnarani, Kuruwanshi, V.B. and Guhey, Arti (2017).A review on biogeochemical linkages of climate change and change in intensity of ultra violet radiation. Internat. J. Plant Sci., 12 (2): 321-326, DOI: 10.15740/HAS/IJPS/12.2/321-326.

Article chronicle : Received : 17.01.2017; Accepted : 30.06.2017 